\title{
Diagnostic dilemmas in a girl with acute glomerulonephritis: Questions
}

\author{
Farah A. Falix ${ }^{1}$ • Michiel J. S. Oosterveld ${ }^{1} \cdot$ Sandrine Florquin $^{2} \cdot$ Jaap W. Groothoff $^{1}$. \\ Antonia H. M. Bouts ${ }^{1}$
}

Received: 31 January 2017 /Revised: 4 February 2017 / Accepted: 7 February 2017 /Published online: 20 March 2017

(C) The Author(s) 2017. This article is published with open access at Springerlink.com

Keywords Macroscopic hematuria · Acute kidney injury · Glomerulonephritis

\section{Case summary}

A 6-year-old girl was referred to our unit with acute kidney injury. The week before, she was evaluated by her general practitioner for asymptomatic macroscopic hematuria. Three weeks earlier, she had complained of a sore throat accompanied by high fever for which her parents administered acetaminophen and ibuprofen. The general practitioner suspected her of having a urinary tract infection (UTI) and prescribed nitrofurantoin. A urinary culture was not obtained. Because of nausea and vomiting, nitrofurantoin was switched to amoxicillin/clavulanate. Four days after initiation of antibiotic treatment, macroscopic hematuria, nausea, and vomiting persisted. Therefore, she was referred to a regional hospital. Her previous medical history was unremarkable, and there were no other complaints. Her urinary output was possibly slightly decreased. Physical examination at the outpatient clinic was unremarkable (heart rate $93 / \mathrm{min}$, respiratory rate $20 / \mathrm{min}$, blood pressure $101 / 55 \mathrm{mmHg}$, temperature $36.7{ }^{\circ} \mathrm{C}$ ).

The answers to these questions can be found at doi: 10.1007/s00467-0173626-3.

Farah A. Falix

f.a.falix@amc.nl

1 Pediatric Nephrology of the Emma Children's Hospital, Academic Medical Center, Amsterdam, Noord-Holland, Netherlands

2 Pathology of the Emma Children's Hospital, Academic Medical Center, Amsterdam, Noord-Holland, Netherlands
Laboratory investigations showed leukocytosis of $26.5 \times$ 10E9/1, with normal hemoglobin and thrombocyte levels, disturbed renal function [creatinine $246 \mu \mathrm{mol} / 1(2.8 \mathrm{mg} / \mathrm{dl})$; urea nitrogen $19.4 \mathrm{mmol} / \mathrm{l}(54 \mathrm{mg} / \mathrm{dl})]$ with normal electrolytes and albumin level, elevated erythrocyte sedimentation rate (ESR) $(68 \mathrm{~mm} / \mathrm{h})$, and C-reactive protein (CRP) $(47 \mathrm{mg} / \mathrm{l})$. Complement 3 and 4 levels were obtained, but results were not directly available. Urinalysis showed nephrotic-range proteinuria and hematuria. A renal ultrasound showed normalsized, slightly hyperechogenic kidneys without signs of obstruction. Based on symptoms, laboratory results, and ultrasound findings, a diagnosis of acute kidney injury due to glomerulonephritis was made. The child was subsequently

Table 1 Laboratory results 1 day after admission

\begin{tabular}{lll}
\hline Tests & Results & Reference value \\
\hline CRP & $82(\mathrm{H})$ & $0-5 \mathrm{mg} / \mathrm{l}$ \\
Hemoglobin & 6.2 & $6-9 \mathrm{mmol} / 1$ \\
Thrombocytes & 498 & $150-600 \mathrm{10E} 9 / 1$ \\
Leukocytes & 16.5 & $4-1510 \mathrm{E} 9 / 1$ \\
PT & 11.2 & $9.7-11.9 \mathrm{~s}$ \\
aPTT & 28 & $22-29 \mathrm{~s}$ \\
Sodium & $131(\mathrm{~L})$ & $135-145 \mathrm{mmol} / 1$ \\
Potassium & 4.6 & $3.5-5 \mathrm{mmol} / 1$ \\
Chloride & $89(\mathrm{~L})$ & $98-107 \mathrm{mmol} / 1$ \\
Calcium & 2.37 & $2.15-2.75 \mathrm{mmol} / 1$ \\
Phosphate & $2.28(\mathrm{H})$ & $1-2.05 \mathrm{mmol} / 1$ \\
Creatinine & $524(\mathrm{H})$ & $35-100 \mu \mathrm{mol} / 1$ \\
Urea nitrogen & $28(\mathrm{H})$ & $1.8-6.4 \mathrm{mmol} / 1$ \\
Albumin & 34 & $37-55 \mathrm{~g} / 1$ \\
LDH & 356 & $0-388 \mathrm{U} / 1$ \\
Complement C3 & $\mathrm{NA}$ & $0.9-1.8 \mathrm{~g} / \mathrm{l}$ \\
Complement C4 & $\mathrm{NA}$ & $0.1-0.4 \mathrm{~g} / \mathrm{l}$ \\
Urine & & \\
$\quad$ Erythrocytes & 61000 & $0-17 / \mathrm{ul}$ \\
Protein/creatinine ratio & 600 & $0-20 \mathrm{mg} / \mathrm{mmol} \mathrm{Cr}$ \\
& &
\end{tabular}

$P T$ prothrombin time, $a P T T$ activated partial thromboplastin time, $N A$ not available, $L$ low, $H$ high, $\mathrm{Cr}$ creatinine 
referred to our unit. On the day after admission, a Sunday, she became oliguric. Laboratory investigations revealed a further rise in creatinine to $524 \mu \mathrm{mol} / 1(5.9 \mathrm{mg} / \mathrm{dl})$, electrolyte disturbances, nephrotic proteinuria, and hematuria (Table 1; laboratory results 1 day after admission).

\section{Questions}

1. What would be your differential diagnosis of the underlying cause of acute kidney injury?

2. What additional laboratory investigations would you perform?

3. Would you prepare the child for kidney biopsy at the first possible moment?
4. Would you blindly start immunosuppressive treatment in the weekend, without additional results?

5. How would you treat the child after renal biopsy and complement results?

\section{Compliance with ethical standards}

Conflict of interest The authors declare to have no conflicts of interest.

Open Access This article is distributed under the terms of the Creative Commons Attribution 4.0 International License (http:// creativecommons.org/licenses/by/4.0/), which permits unrestricted use, distribution, and reproduction in any medium, provided you give appropriate credit to the original author(s) and the source, provide a link to the Creative Commons license, and indicate if changes were made. 